5. Русенко I. Я. Реформування національної правової системи України: філософсько-правовий підхід // Часопис Київського університету права. - 2014. - №1. - С. 67-72.

6. Хаустова М. Г. Проблеми і перспективи розвитку правової системи України в умовах глобалізації // Вісник Національної академії правових наук України. - 2014. - №1 (76). - С. 54-63.

\title{
Варич О. Г. Правовий моніторинг як сучасний вектор ефективного розвитку правової системи
}

У статті досліджені проблеми сучасних векторів розвитку інституту правового моніторингу. 3'ясовано етапи (стадіi) правового моніторингу, виокремлено основні правові складові, що у значній мірі впливають на процес оцінки ефективності нормативно-правових актів, зокрема, якість самого законодавства, його соціальна корисність, необхідність оцінювання поставлених та досягнутих цілей нормативно-правового акта, ефективність правозастосовчої діяльності, рівень правосвідомості правозастосовника та суспільства.

Ключові слова: правовий моніторинг, ефективність дії нормативно-правового акта, правове регулювання, якість та ефективність законодавства.

\section{Varych O. G. Legal monitoring as modern vector of effective development of the legal system}

Summary. In the article investigational problems of modern vectors of development of institute of the legal monitoring. The stages of the legal monitoring are found out, basic legal constituents are distinguished, that in a considerable measure influence on the process of estimation of efficiency of normatively-legal acts, in particular, quality of legislation, him social utility, necessity of evaluation of the put and attained aims of normatively-legal act, efficiency of legislation activity, level of sense of justice of low enforcers and societies.

Key words: legal monitoring, efficiency of action of normatively-legal act, legal adjusting, quality and efficiency of legislation.

DOI: 10.33.66.3/2524-017X-2019-10-108-111

УдК 340.1

Вячеслав Юрійович Васецький, кандидат юридичних наук, науковий співробітник відділу теорії держави і права Інституту держави і права ім. В.М. Корецького НАН Украӥни

\section{МАГДЕБУРЗЬКЕ ПРАВО ЯК ВИТОК ІСТОРИЧНО-ПРАВОВОГО РОЗВИТКУ МІСЦЕВОГО САМОВРЯДУВАННЯ В УКРАЇНІ}

Постановка проблеми та аналіз останніх досліджень та публікацій. Магдебурзьке право в містах України існувало протягом певного досить довгого часу. Воно має значення не тільки в аспекті історичного розвитку нашої країни, а й виявляє, так би мовити, пролонговану дію на події сьогодення стосовно становлення місцевого самоврядування, яке визначається як право територіальної громади... самостійно вирішувати питання місцевого значення в межах Конституції і законів України [1]. Місцеве самоврядування - політико-правовий інститут народовладдя, через який здійснюється управління місцевими справами шляхом самоорганізації жителів певної території і при сприянні держави. Місцеве самоврядування зародилося у Європі в часи Середньовіччя. Класичної форми у вигляді Магдебурзького права воно набуло в містах, починаючи 3 XIII ст. [2, с. 731-732]. Відповідно до Конституції прийнятий Закон України «Про місцеве самоврядування в Україні», який визначає систему та гарантії місцевого самоврядування в Україні, засади організації та діяльності, правового статусу і відповідальності органів та посадових осіб місцевого самоврядування.

У зв'язку з актуальністю, науковим і практичним значенням питання місцевого самоврядування, а також його історичною формою як Магдебурзького права, цією проблемою займалась плеяда українських науковців. Зокрема, І. Усенко, Ю. Кириченко, М. Кобилецький. І. Бойко, А. Бортнікова та ін. 
Актуальність проблеми зумовлена також тим, що вона носить об'єднавчий характер, оскільки Магдебурзьке право у певній формі діяло у багатьох містах Центральної і Східної Європи, що обумовило загальну дослідницьку тематику з цього питання у наукових колах Республіки Польща, Німеччини та українських вчених. Наприклад, I. Бойко аналізує застосування Магдебурзького права у Галичині, коли вона була у складі Польського королівства, та його значення для становлення міського самоврядування західноукраїнських міст [4, с. 97-98]. Крім того, актуальність проблеми обумовлена практичною необхідністю керуватися існуючими конкретними нормами, які закладені у відповідних правових актах України.

Метою дослідження $є$ вивчення причин виникнення феодально-міського права (Магдебурзького права), умов його поширення в країнах східної Європи та України, визначення зв'язку цієї правової інституції з іншими елементами правової системи тодішньої України.

Основні результати дослідження. І. Литвиненко наголошує, що для України існування ідеї інституту місцевого самоврядування в тій чи іншій формі не $\epsilon$ новим. Україна протягом тисячі років намагалась створити власну повноцінну державу, і протягом всієї історії іiі існування не припинялись спроби становлення і розвитку цього інституту [5, с. 43$]$.

Ю. Кириченко зазначає різні погляди науковців на час виникнення місцевого самоврядування в Європі: одні вчені вважають, що місцеве самоврядування виникло в Європі в період переходу від феодалізму до буржуазного ладу, тобто було пов'язано з буржуазно-демократичними революціями; інші вважають, що місцеве самоврядування - це довготривале явище в соціальному та політичному житті людства і його витоки сягають громадського та племінного самоврядування в додержавницький період. Досить часто в науковій літературі наголошується, що саме на підставі Магдебурзького права середньовічне міське самоврядування поклало початок становленню місцевого самоврядування в сучасному його розумінні та було його першою історичною формою [6, с. 361].

Починаючи 3 XII ст., на Європейському континенті утворюються міста, які дуже швидко сформували власну правову одиницю. Навколо причин виникнення і розвитку середньовічних міст серед учених відсутня єдність. Так, наприклад, «романістична» теорія (Тьєрі, Гизо, Фюстель де Куланж, Савіньї) стверджувала, що середньовічні міста були продовженням розвитку міст в пізній Римській імперії. Ці твердження базувалися на тому, що деякі міста виникли на терені давньоримських поселень, а середньовічний муніципальний устрій мав пряму наступність від римського. Однак ця теорія не відповідає на питання стосовно муніципального устрою в містах епохи Середньовіччя, де ніколи не було римських міст.

Як зауважували Ейхгорн та Нич, середньовічне місто виникло та отримало свій розвиток внаслідок феодальної вотчини, проте вотчинне право не сформувалося в окреме міське право. Прибічники «маркової» теорії (Мауер, фон Бєлов) виокремлюють місто з вільної сільської громади (марки), яка формує власні звичаї [7, с. 110].

Поява та формування феодального міського права в Україні за західноєвропейським зразком спостерігається, починаючи з XIII ст. Правовою основою функціонування Києва, як загалом і інших українських міст, до кінця XV ст. було звичаєве право та Руська правда. У 1494 р. у Києві спостерігається посилення влади Великого князя Литовського. У цей рік міщани отримали усну грамоту Великого князя Литовського Олександра, у якій зазначалося, що їх наділяли тими самими правами, «як за Великого князя Вітовта» [8, с. 305-336], що свідчить про мінімальний характер регресу правового захисту міста. В цей період середньовічне міське право як Західної, так і Східної Європи починає становити особливу правову систему, норми якої регулювали види суспільних відносин (публічного і приватноправового характеру), що виникають в процесі організації міського управління. Проте в 1496 р. було підписано Люблінську унію і на офіційному рівні утворено Річ Посполиту, тобто Київ опинився у складі нової держави, де панувало католицтво на противагу православної віри більшості місцевого населення. Одночасно з цим, у середньовічній Європі триває епоха так званого «Готичного відродження», яка збіглася з посиленням ролі міста в тогочасному державному утворенні. Саме тоді й виникло гасло «міське повітря робить людину вільною».

Ураховуючи віддаленість українських земель від основної арени європейських політичних подій та їх перебування у складі інших країн, торгово-грошові відносини були повільнішими та розвиток соціально-економічних прав також відбувався не так швидко, як, наприклад, у країнах Європи в часи Готичного відродження [9, с. 40]. В Україні існували незалежні торгові міста, такі, як Київ, Львів, Луцьк, Володимир-Волинський, Перемишль. Але первісний капітал тут циркулював в їх ме- 
Васецький В. Ю. Магдебурзьке право як виток історично-правового розвитку місцевого...

жах, не спрямовуючись на розбудову держави, прогресивний розвиток якої тоді було перервано. Крім іншого, на українських землях правові інститути були не настільки розвинуті, щоб виникала необхідність та можливість їхньої систематизації. Нові тенденції західноєвропейської юридичної науки мали культурний вплив хіба що на невеликий відсоток населення - на студентів Острозької та Києво-Могилянської академій. Разом з цим, тогочасне українське право залишалось не лише одним зджерел права всіх руських земель у складі Великого князівства Литовського, а й одним 3 визначних чинників самоідентифікації руського населення.

На землях Великого князівства Литовського, а потім і Речі Посполитої на всіх рівнях проводились заходи 3 державної централізації. Одним з найпріоритетніших завдань була необхідність державних чиновників спиратися на міста у своїй політичній діяльності. Саме тоді на території тодішньої Речі Посполитої, до складу якої входила сучасна Україна, поширюється Магдебурзьке право, яке надавалося привілеєм польського короля, який засвідчував, що дане місто або містечко звільняли не лише від судової, а й виконавчої влади власника, на землі якого воно було розташоване. Із загальнодержавних повинностей залишалася тільки військова. Мешканці міст і містечок самостійно утримували міську адміністрацію, сплачували податки духовенству. 3 них стягували також грошові податки на ремонтні роботи. Сутність Магдебурзького права полягала, насамперед, у тому, що воно надавало мешканцям значні права на самоврядування. У тих містах, куди приїжджали багато купців, мешканці мали право будувати гостинний двір. Серед головних джерел надходжень до казни власників міста найбільше значення мала торгівля [7, с. 279].

У XV ст. відбувається відродження міста Києва та інших міст України на основі так званого Магдебурзького права міського самоврядування. Із здобуттям Києвом Магдебурзького права православні та уніати отримали більше прав порівняно з тими, що були раніше [11, с. 169]. Відтак, основою київського життя 3 початку 90-x pp. XV ст. до кінця XVIII ст. стало Магдебурзьке право, яке й визначало статус міста не лише у Великому князівстві Литовському та Речі Посполитій, а й за часів Гетьманщини під безпосередньою владою Російської імперії. Статус Києва, як вільного міста, залишався переважно непорушним, хоч, зрозуміло, і зазнавав певних змін, спричинених пануванням різних володарів.

Члени органів міського самоврядування: війт, бургомістри, і радці, - обирались лише із заможних киян. Війт затверджувався королем. Його кандидатура мала бути запропонованою самими міщанами. Головою міського суду грамота на Магдебурзьке право проголошувала війта. Його судові повноваження у цій грамоті визначались досить широко - в його руках зосереджувалась вся карна влада. Разом з тим у судовому відношенні війт був у безпосередній залежності від Великого князя, в справи міського самоврядування в реальності постійно втручались представники київської військової адміністрації. На частину населення Києва, що не належала до стану міщан, Магдебурзьке право не розповсюджувалось. «Господарських» міщан, що перебували під юрисдикцією замку, судив замковий суд на чолі з воєводою, а на феодально залежних, в тому числі, і духовних, зокрема монастирських - розповсюджувався феодальний суд, який здійснювався безпосередньо феодалом, або уповноваженою ним на це особою.

Отже, по-перше, Магдебурзьке право України входило в систему права Західної Європи, що підтверджує належність правової системи України до романо-германської правової сім'ї.

По-друге, поширенню магдебурзького права в українських містах сприяла низка соціальноекономічних та політичних чинників. Так, прискорений розвиток сільського господарства, посилення впливу товарно-грошових відносин сприяли піднесенню українських міст та їх жителів, що вимагало відповідної правової регламентації. Запровадження Магдебурзького права в українських містах поширювалось під польським впливом із урахуванням вітчизняних традицій звичаєвого права, однак це не був оригінальний процес, який відбувався із значним спізненням порівняно з іншими містами Західної Свропи. Магдебурзьке право ставало не лише способом модернізації суспільних відносин, а й інструментом політичного впливу Польської корони, спрямованим на інкорпорацію українських земель й Великого князівства Литовського до Польщі.

На сьогодні істориками не до кінця з'ясовано питання співвідношення процесів поширення Магдебурзького права в містах України і політики централізації, що характеризувалося зміцненням бюрократичної опіки збоку влади, неминучим у процесі утворення централізованої держави, якою було Велике Литовське князівство. Як зазначає Ю. Кириченко, наслідком запровадження Магдебурзького права стало виведення більшості міст із-під влади феодалів, князів та воєвод, скасування 
норм звичаєвого права, утворення та розвиток нових політико-правових форм і методів організації суспільства тощо. На його думку, Магдебурзьке право створило правову основу становлення і розвитку місцевого самоврядування в сучасному його розумінні [6, с. 366].

Основний висновок полягає у значенні Магдебурзького права як основи для розвитку місцевого самоврядування в Україні, отримання історичного досвіду, запозичення в сучасних умовах досягнень місцевого самоврядування європейських країн та запровадження його у національну систему місцевого самоврядування, пристосування відповідних національних правових норм, стандартів та процедур.

Відмінність між європеїзацією в минулих століттях та сучасною полягає в тому, що, по-перше, сьогодні все це відбувається без нав'язувань і насаджень, а по-друге, йдеться не про копіювання якоїсь конкретної зарубіжної моделі місцевого самоврядування, а про вироблення власної національної моделі, заснованої на основі застосування визнаних у Свропі та світі основних сучасних принципів врядування.

\section{Список використаних джерел}

1. Конституція України // Відомості Верховної Ради України (ВВР). - 1996. - № 30. - Ст. 141.

2. Погорілко В. Ф., Батанов О. В. Місцеве самоврядування. Юридична енциклопедія : в 6 т. / Редкол. : Ю. С.Шемчученко та ін. - К. : Укр. енцикл., 2001. - 792 с.

3. Закон України «Про місцеве самоврядування в Україні» // Відомості Верховної Ради України (ВВР). - 1997. № 24. - Ст.170.

4. Бойко О. Д. Історія України : посіб. [для студ. вищих навч. закл.] / О. Д. Бойко. - К. : Видав. центр «Академія», 1999. - 568 c.

5. Литвиненко І. Л. Історичні традиції становлення і розвитку місцевого самоврядування в Україні / І. Л. Литвиненко // Вісник Хмельницького інституту регіонального управління та права. - 2002. - № 1. - С. 43-49.

6. Кириченко Ю. М. Поширення Магдебурзького права та його особливості в містах України / Ю. М. Кириченко // Форум права. - 2011. - № 4. - С. 361-366.

7. История средних векав : учеб. для студ. ист. фак. пед. ин-в / М. Л. Абрамсон, А. А. Кириллова, Н. Ф. Колесницкий и др. Под ред. Н. Ф. Колесницкого. - 2-е изд., испр. и доп. - М. : Просвещение, 1986. - 575 с.

8. История Киева : в 4 т. - Т. 1: Древний и средневековый Киев / Гл. ред. Кондуфор Ю. Ю. - К. : Наукова думка, 1982. $-408 \mathrm{c}$.

9. Яковенко Н. М. Українська шляхта кінця XIV до середини XVII ст. (Волинь і Центральна Україна).- К. : Критика, 2008. - 470 с.

10. Кіселичник В. Львівське міське право: поняття, джерела, періодизація та зміст // Вісник ЛНУ. Серія юридична. - 2004.- Вип. 39.

11. Павленко Ю. В. Нарис історії Києва / Ю. В. Павленко. - К. : Фенікс, 2004. - 480 с.

Васецький В. Ю. Магдебурзьке право як виток історично-правового розвитку місцевого самоврядування в Україні

Існування Магдебурзького права в містах України має вплив на події сьогодення стосовно становлення місцевого самоврядування. Метою дослідження є вивчення причин виникнення Магдебурзького права, умов його поширення в країнах Східної Свропи та України, визначення зв'язку цієї правової інституції з іншими елементами правової системи тодішньої України. Подано історичний аспект поширення Магдебурзького права в містах України. Магдебурзьке право України входило в систему права Західної Європи, що підтверджує належність правової системи України до романо-германської правової сім’ї. Незважаючи на зовнішній вплив, поширенню Магдебурзького права в українських містах сприяли внутрішні соціально-економічні та політичні чинники. Робиться висновок про значення Магдебурзького права для набуття необхідного історичного досвіду і основи для розвитку місцевого самоврядування в Україні з використанням досягнень європейських країн.

Ключові слова: місцеве самоврядування, Магдебурзьке право, місцеві органи влади.

Vasetsky V. Y. Magdeburg Law as an Origins of Historical and Legal Development of Local Self-Government in Ukraine

Magdeburg Law in the cities of Ukraine existed during the Middle Ages for quite some time. It matters not only in the aspect of the historical development of our country, but also has an impact on the events of the present with regard to the formation of local self-government. The purpose of the paper is to study the causes of the Magdeburg Law, the conditions 
for its extension in the countries of Eastern Europe and Ukraine, the definition of the connection of this legal institution with other elements of the legal system in Ukraine at that time. The problem is urgent and has a scientific and practical significance as an important historical form of local self-government.

In the scientific literature it is noted that just on the basis of the Magdeburg Law, medieval city self-government marked the beginning of the formation of local self-government in its modern sense and was its first historical form. The spread of the Magdeburg Law in the cities of Ukraine took place at a time when Ukraine was part of the Rzecz Pospolita. The basis of life in Kiev since the early 90's XV century by the end of the XVIII century Magdeburg Law, which determined the status of the city not only in the Grand Duchy of Lithuania and the Rzecz Pospolita, but also during the Hetmanate period under the direct authority of the Russian Empire. Despite the external influence, the extension of Magdeburg law in Ukrainian cities was facilitated by internal socio-economic and political factors.

The Magdeburg Law of Ukraine was part of the system of the law of Western Europe, which confirms the belonging of the legal system of Ukraine to the Roman-Germanic legal family. A number of socio-economic and political factors contributed to the expansion of Magdeburg Law in Ukrainian cities: accelerated development of agriculture, strengthening of the influence of commodity-money relations, which contributed to the elevation of Ukrainian cities and their inhabitants.

A conclusion is made about the significance of the Magdeburg Law in order to acquire the necessary historical experience and the basis for the development of local self-government in Ukraine, using the achievements of European countries.

Key words: local self-government, Magdeburg law, local authorities.

DOI: $10.33 .66 .3 / 2524-017 X-2019-10-111-115$

УДК 342.8; 324

\author{
Дарія Любомирівна Вімюк, \\ кандидат юридичних наук, дочент кафедри, \\ заступник завідувача кафедри теорії, \\ історії права і держави та конституиійного права \\ з наукової роботи ННІ права УДФСУ \\ Ольга Анатоліївна Павлюх, \\ старший викладач кафедри теорії, \\ історії права і держави та конституиійного права \\ ННІ права УДФСУ
}

\title{
ВИБОРИ ЯК ФОРМА БЕЗПОСЕРЕДНЬОЇ ДЕМОКРАТІЇ: ТЕОРЕТИКО-ПРАВОВИЙ АСПЕКТ
}

Постановка проблеми. Актуальність обраної теми дослідження полягає у тому, що вибори 3 найдавніших часів вважалися однією 3 найдієвіших та найефективніших форм безпосередньої демократії як в Україні, так і в інших державах. Стаття 69 Конституції України визначає, що «народне волевиявлення здійснюється через вибори, референдум та інші форми безпосередньої демократії» [1]. У сучасній науковій літературі з конституційного (державного) права популяризуються такі форми безпосередньої демократії як вибори, референдуми, відкликання, народна законодавча ініціатива, опитування населення, збори громадян тощо. Однак найбільша увага приділяється виборам як формі безпосередньої демократії, яка впливає на формування органів представницької демократії.

Вибори як форма безпосередньої демократії мають давню історію, сприяють реалізації народного суверенітету та $є$ показником рівня розвитку правової держави, громадянського суспільства, прав і свобод людини і громадянина тощо. Серед найяскравіших прикладів застосування виборів як важливої форми безпосередньої демократії з історії побудови української державності $є$ вибори Президента України, які відбулися 1 грудня 1991 р. одночасно з проведенням Всеукраїнського референдуму, який надав найвищої юридичної сили Акту проголошення незалежності України. Також це президентські вибори у листопаді - грудні 2004 року після Помаранчевої революції, яка була організована і проведена прихильниками Віктора Ющенка, та після Майдану 2014 року, який отримав назву «Революція Гідності» або «Євромайдан». Ці приклади застосування виборів 